\title{
Pemberdayaan UMKM dan Kelompok Dasa Wisma Berbasis Teknologi Informasi di Desa Bangunjiwo Kabupaten Bantul
}

\author{
SMEs and Social Group Empowerment through Information Technology in Bangunjiwo \\ Village, Bantul Regency
}

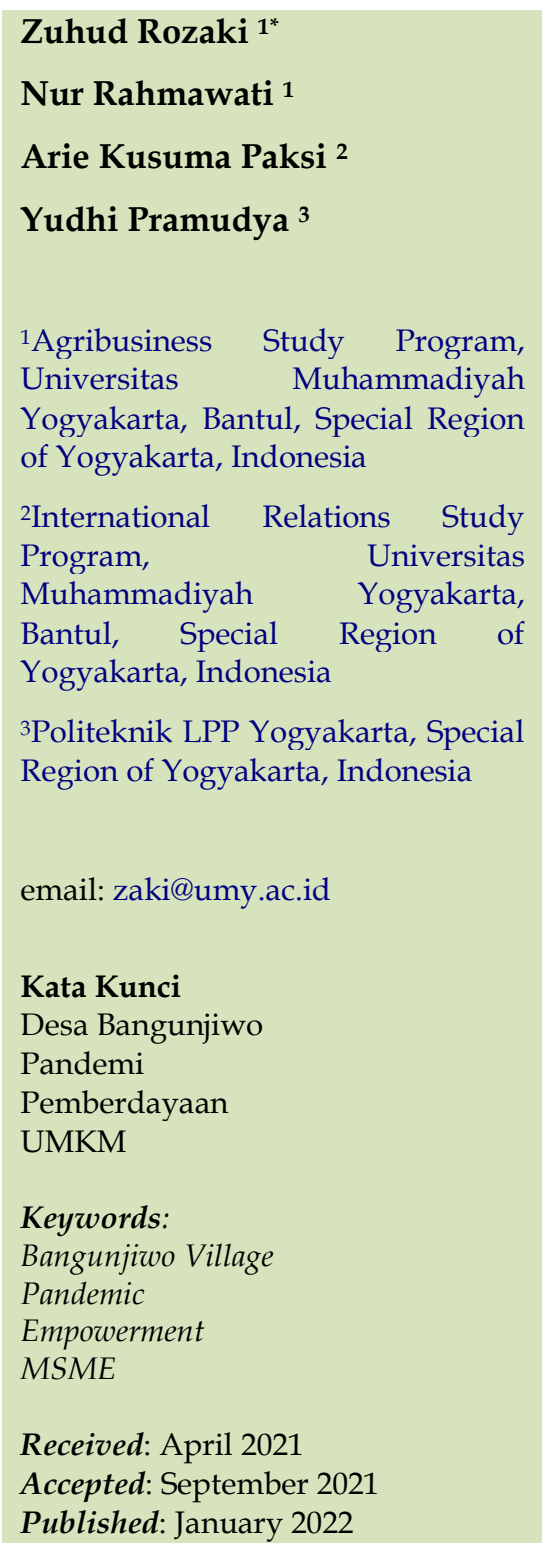

\begin{abstract}
Abstrak
Pandemi Covid-19 bedampak pada sector ekonomi, banyak dari masyarakat yang berusaha bertahan karena dampak pandemi ini. Kegiatan pengabdian ini bertujuan untuk memberdayakan UMKM dan Kelompok Dasawisma yang ada di Desa Bangunjiwo, Kabupaten Bantul untuk bisa lebih berkembang dan bertahan atau pulih dari dampak pandemi. Metode yang digunakan adalah pelatihan dan pendampingan. Kegiatan pengabdian ini berjalan dengan baik berkat Kerjasama semua mitra. Upaya peningkatan kapasitas pemasaran mitra dirasa meningkat dengan adanya pengabdian ini, mitra menjadi sadar bahwa pada masa digital seperti ini, usaha mereka harus lebih up to date terhadap zaman dan juga adaptif terhadap permasalah yang sudah ada. Mitra Kelompok Dasa Wisma juga mengalami kenaikan kapasitas terutama dalam ketrampilan mereka dalam mengolah makanan menjadi frozen food. Harapannya mitra bisa terus berkembang dan mampu beradaptasi Ketika masalah seperti pandemi ini muncul.
\end{abstract}

\section{Abstract}

The Covid-19 pandemic has an impact on the economic sector. Many people are trying to survive because of the effects of this pandemic. This service activity aims to empower SMEs and the Dasawisma Group in Bangunjiwo Village, Bantul Regency, to be more developed and survive or recover from the impact of the pandemic. The methods used are training and mentoring. This service activity went well thanks to the cooperation of all partners. Efforts to increase the marketing capacity of partners are felt to have grown with this dedication. Partners have become aware that in a digital era like this, their business must be more up to date with the times and adaptive to existing problems. Dasa Wisma Group partners also experienced an increase in capacity, especially in processing food into frozen food. The hope is that partners can continue developing and adapting when problems like this pandemic arise.

(C) 2022 Zuhud Rozaki, Nur Rahmawati, Arie Kusuma Paksi, Yudhi Pramudya. Published by Institute for Research and Community Services Universitas Muhammadiyah Palangkaraya. This is Open Access article under the CCBY-SA License (http://creativecommons.org/licenses/by-sa/4.0/). DOI: https:// doi.org/10.33084/pengabdianmu.v7i1.2244

\section{PENDAHULUAN}

Akhir tahun 2019 muncul sebuah wabah baru yang disebut Coronavirus disease 2019 (Covid-19) (Kholisotin \& Sadar, 2021). Dalam waktu singkat Organisasi Kesehatan Dunia (WHO) menetapkan wabah ini sebagai pandemi karena skala penyebarannya mencakup lebih dari 219 negara dan wilayah di seluruh dunia. Covid-19 digolongkan sebagai penyakit mematikan sebab memakan banyak korban jiwa. Indonesia pun terdapat 707.000 kasus Covid-19 per Desember 2020 
dengan jumlah kematian mencapai 20.994. Hal ini mendorong pemerintah Indonesia membuat himbauan serta seperangkat kebijakan pembatasan kegiatan sosial dan fisik (social distancing) demi menekan lonjakan kasus Covid-19 (Kar et al., 2020; Mboera et al., 2020). Situasi ini kemudian berimbas pada berbagai sektor termasuk ekonomi nasional yang semakin lesu. Dampak pandemi Covid-19 khususnya untuk keberlangsungan Usaha Mikro Kecil dan Menengah (UMKM) sangat besar, survei Kementerian Koperasi dan UMKM menunjukkan bahwa sebanyak 47 persen UMKM harus gulung tikar pada bulan Mei 2020 terkait terganggunya distribusi dan melemahnya permintaan (Nicola et al., 2020; Simms \& Rowson, 2003).

Dampak pandemi Covid-19 turut dirasakan oleh beberapa UMKM yang berada di Desa Bangunjiwo. Permintaan menurun drastis seiring dengan membeludaknya kasus Covid-19, bahkan hampir tidak ada pesanan (Rozaki, 2020; Taufik \& Ayuningtyas, 2020). Secara otomatis hal ini telah menurunkan omset usaha dan mengancam keberlangsungan UMKM (Djalante et al., 2020). Desa Bangunjiwo sendiri terletak di Kecamatan Kasihan, Kabupaten Bantul, Daerah Istimewa Yogyakarta, banyak UMKM yang terletak di daerah ini yang mengalami kesulitasn dari pandemi dimana banyak masyarakat yang dibatasi pergerakannya.

Selain kesulitan akibat pandemi yang membuat tidak memungkinkannya promosi dan penjualan langsung (person to person), UMKM di Desa Bangunjiwo juga memiliki tantangan yang tidak kalah berat yakni globalisasi dimana banyak produk luar terutama dari Cina yang memiliki harga yang lebih murah. Globalisasi telah menyebabkan beberapa perubahan besar termasuk semakin canggihnya teknologi dan pasar bebas, mayoritas masyarakat dan informasi juga telah berpindah ke digital platform (Latiff \& Safiee, 2015). Hal ini menuntut pelaku UMKM untuk memiliki efisiensi yang tinggi dengan pemilihan strategi pemasaran yang tepat agar mampu menjadi kompetitif. UMKM harus memiliki kemampuan dalam penguasaan teknologi dan informasi serta menghasilkan produk yang menarik (Irawan, 2020). Sudah banyak usaha atau produk yang banyak mengandalkan teknologi dan informasi untuk promosi serta menjaring banyak konsumen, salah satunya lewat media sosial seperti Instragram (Hashim, 2017). Sudah banyak terbukti upaya pengembangan lewat media sosial ini mampu meningkatkan omset dari penjualan UMKM, apalagi di masa pandemi ini banyak masyarakat memilih untuk tidak keluar rumah dan berbelanja lewat online (Lubis \& Junaidi, 2016). Fokus pemberdayaan yang dilakukan akan terkait dengan pemasaran dan pengiklanan produk UMKM secara online (Fidiana et al., 2020). Diharapkan dengan pemberdayaan yang dilaksanakan, UMKM dapat meningkatkan produktifitasnya pada masa pandemi melalui promosi di media sosial dan situs marketplace.

\section{METODE}

Lokasi pengabdian adalah di Desa Bangunjiwo, Kecamatan Kasihan, Kabupaten Bantul, Daerah Istimewa Yogyakarta. Sebelum dilakukannya pengabdian, terlebih dahulu dilakukan observasi dan wawancara kepada tokoh masyarakat setempat terkait dampak pandemi Covid-19, kemudian dilakukan analisis bersama anggota kelompok pengabdian lainnya untuk menentukan tema dan pokok masalah apa yang perlu dibantu dan diangkat menjadi teman pengabdian ini.

Metode pengabdian yang digunakan pada karya ini terdiri dari pelatihan dan pendampingan. Pertama yaitu peningkatan strategi marketing dengan pendampingan dan pelaithan pembuatan akun Shopee untuk UMKM mitra. Kegiatan dilakukan dengan memberikan informasi (gambaran) tata cara membuat akun, upload produk, dan penjelasan terkait fiturfitur yang ada di Shopee secara detail, kegiatan ini juga didukung dengan pendampingan pengoptimalan media sosial seperti Instagram dalam upaya promosi produk.

Kedua yaitu pendampingan pembuatan katalog online untuk UMKM mitra, kegiatan diawali dengan menentukan konsep foto terlebih dahulu untuk mengetahui kebutuhan properti apa saja yang dibutuhkan dan dilanjutkan dengan sesi foto produk yang kemudian hasilnya diupload di media sosial Instagram. Ketiga yaitu pendampingan dan pelatihan pembukuan keuangan, Kegiatan ini dilakukan dengan memberikan tutorial tata cara pengoperasian aplikasi Buku Kas secara langsung kepada Mitra. 
Keempat yaitu mendampingi mitra dalam pameran virtual, kegiatan ini dilakukan dengan mengikutsertakan mitra UMKM dalam kegiatan UMKM Virtual Exhibition yang diadakan oleh LP3M UMY yang mana kegiatan ini dilakukan dengan mempresentasikan produk-produk dari mitra UMKM, produk juga di display dalam website https://expo.umy.ac.id/. Kelima yaitu peningkatan produktivitas Kelompok Dasawisma dengan pelatihan pembuatan frozen food. Kegiatan dilaksanakan dengan memberikan 3 video tutorial pembuatan frozen food yakni potato cheese stick, creamy yummy bread, dan fried choco banana yang telah dibuat kelompok kami melalui grup WhatsApp, kemudian ibu-ibu anggota Dasawisma mempraktikan pembuatan produk frozen food tersebut. Keenam yaitu penyediaan alat cuci tangan untuk membantu peningkatan budaya protokol Kesehatan untuk UMKM mitra, kegiatan ini dilakukan dengan menghibahkan wastafel kepada mushola dekat lokasi mitra UMKM Banyu Biru Craft, menghibahkan Perlengkapan cuci tangan kepada kedua mitra UMKM serta mushola di dekat lokasi mitra UMKM Pisau Batik Logam Mr. Diman, serta hibah masker kepada semua mitra dan masyarakat RT. 03 Kalirandu, Bangunjiwo. Kontribusi dari setiap anggota pengabdian bisa dilihat pada Tabel I.

Tabel I. Jadwal dan pembagian kerja

\begin{tabular}{|c|c|c|c|c|c|c|}
\hline \multirow{2}{*}{ Nama Kegiatan } & \multicolumn{6}{|c|}{ Bulan } \\
\hline & 1 & 2 & 3 & 4 & 5 & 6 \\
\hline Survey & $\begin{array}{l}\text { ZR \& } \\
\text { AKP }\end{array}$ & & & & & \\
\hline Perijinan & & NR & & & & \\
\hline $\begin{array}{l}\text { Pendampingan pembuatan dan penggunaan akun sosial media } \\
\text { Instagram }\end{array}$ & & & YP & $\begin{array}{l}\text { ZR \& } \\
\text { YP }\end{array}$ & & \\
\hline $\begin{array}{l}\text { Pendampingan pembuatan dan penggunaan akun marketplace Shopee } \\
\text { untuk pemasaran produk }\end{array}$ & & & & & $\begin{array}{l}\text { NR \& } \\
\text { AKP }\end{array}$ & $\mathrm{AKP}$ \\
\hline Pembuatan desain produk & & & $\mathrm{ZR}$ & & & \\
\hline Pembuatan katalog & & & YP & & & \\
\hline Pembaharuan kemasan produk & & & & AKP & AKP & \\
\hline $\begin{array}{l}\text { Penyuluhan terkait pembukuan keuangan usaha dengan metode } \\
\text { pencatatan hard dan soft file }\end{array}$ & & & & & & NR \\
\hline
\end{tabular}

\section{HASIL DAN PEMBAHASAN}

\section{Kondisi umum lokasi dan mitra}

Desa Bangunjiwo terletak di Kecamatan Kasihan, Kabupaten Bantul, Daerah Istimewa Yogyakarta. Desa ini memiliki luas $15.43 \mathrm{~km}^{2}$ dan merupakaan penggabungan dari 4 kelurahan yaitu Kelurahan Paitan, Sribitan, Kasongan, dan Bangen. Terdapat 19 pedukuhan di Desa Bangunjiwo yang meliputi 144 Rukun Tetangga. Desa Bangunjiwo berbatasan dengan Desa Tamantirto disebelah utara, Desa Guwosari disebelah selatan, Desa Triwidadi disebelah barat, dan Desa Tirtonirmolo disebelah timur. Jarak Desa Bangunjiwo dari ibu kota kabupaten adalah sekitar $8 \mathrm{~km}$ dan dari ibu kota DIY adalah sekitar $10 \mathrm{~km}$. Topografi Desa Bangunjiwo didominasi dataran tinggi/pegunungan dengan tata guna lahan 35\% permukiman, 13\% sawah, dan 52\% perkebunan serta hutan. Desa Bangunjiwo memiliki jumlah penduduk sebesar 28.129 jiwa dengan 10.955 kepala keluarga dan tingkat kepadatan penduduk 1.822,50/km (Badan Pusat Statistik Kabupaten Bantul, 2020).

1. UMKM Pisau Batik Logam Mr. Diman

UMKM Pisau Batik Logam Mr. Diman yang bergerak di bidang kerajinan tangan (handy craft) merupakan usaha yang didirikan oleh BapakSudiman yang juga merupakan founder dari produk tersebut. Bapak Sudiman melakukan proses produksi dibantu dengan beberapa orang karyawan dan lokasi produksi berpusat di rumahnya yang beralamat di Kalirandu RT 03, Bangunjiwo, Kasihan, Bantul. Pisau Batik Logam ini telah memenangkan berbagai macam perlombaan kerajinan tangan baik daerah maupun nasional.

2. UMKM Banyu Biru Craft

Home industri ini dirintis berdua oleh Bapak Darmawan dan istrinya Ibu Sri Suharti sejak tahun 2006 pada awal pernikahan mereka. Setelah lima tahun berjalan, kondisi usaha dirasakan mulai menapaki perkembangan yang 
prospektif, karena hampir setiap hari ada order. Bapak Darmawan memilih berwira usaha karena dibentuk oleh kondisi lingkungan Jipangan yang merupakan sentra kerajinan kipas bambu.

3. Kelompok Dasawisma Cempaka 1

Dasawisma Cempaka 1 merupakan organisasi masyarakat yang diketuai oleh Ibu Marsini dibawah PKK Desa Bangunjiwo yang beranggotakan ibu-ibu di RT. 03 Dukuh Kalirandu, Kasihan, Bantul. Dasawisma Cempaka 1 melakukan pertemuan rutin sekali dalam seminggu yakni pada hari Kamis. Kegiatan rutin yang dilakukan ialah arisan, tidak hanya bertujuan untuk arisan pertemuan ini dilakukan juga untuk mempererat silaturahmi serta sebagai wadah para anggotanya untuk menyampaikan aspirasinya sehingga dapat diteruskan dalam rapat PKK Desa Bangunjiwo.

\section{Pelaksanaan kegiatan}

1. Peningkatan strategi marketing

Pemasaran (marketing) perhatiannya tertuju pada bagaimana dapat memenuhi atau memuaskan kebutuhan dari para konsumen melalui berbagai saluran distribusi tertentu dengan produk-produk yang dapat ditawarkan kepada mereka, sehingga pemasaran lebih ditekankan pada orientasi konsumen (consumers oriented). Dengan demikian, strategi marketing tidak berada pada kondisi yang statis, namun dalam keadaan yang sangat dinamis sesuai dengan perkembangan dalam dunia usaha pada umumnya. Evaluasi dan modifikasi senantiasa perlu dilakukan sesuai dengan perubahan yang ada dan tuntutan kondisi sesungguhnya yang terjadi. Adapun kegiatan-kegiatan yang dilaksanakan oleh tim pengabdian dalam rangka program ini yaitu:

a. Pengoptimalisasian akun media sosial Instagram.

Memasuki zaman yang serba digital maka sudah seharusnya semua beradaptasi dengan kemajuan teknologi salah satunya dengan memiliki media sosial. Melihat banyaknya pengguna Instagram maka kami melihat peluang pemasaran produk melalui Instagram merupakan salah satu cara untuk mendapatkan konsumen yang lebih luas (Fidiana et al., 2020; Latiff \& Safiee, 2015; Setyowardhani et al., 2019). Tim pengabdian ini mengoptimalisasikan akun Instagram milik Banyu Biru Craft dengan memperbaharui semua komponen mulai dari nama akun, biodata akun, menata feed Instagram. Khusus untuk feed Instagram, tim pengabdian melalukan foto produk untuk mendapatkan foto produk yang apik dan ciamik yang dapat disajikan di unggahan Instagram agar menarik pengunjung. Tim pengabdian melakukan pendampingan secara langsung kepada Bapak Darmawan tentang bagaimana cara mengoperasikan Instagram, kapan saja waktu yang baik untuk mengunggah post dan instagram story, penggunaan tagar untuk menarik pengunjung. Sedangkan untuk pengoptimalisasian Instagram Pisau Batik Logam Mr. Diman, foto produk diambil kembali untuk memperbaharui foto dengan produk Pisau Batik Logam yang lebih baru yang nantinya akan diunggah di akun Instagram Pisau Batik Logam Mr. Diman.

b. Pembuatan Katalog

Instagram Banyu Biru Craft ini juga berfungsi sebagai katalog online dimana para konsumen dapat melihat berbagai koleksi, jenis kipas yang disediakan oleh Banyu Biru Craft. Pembuatan katalog ini dimulai dengan menyiapkan properti untuk mendukung sesi foto produk (Gambar 1). Sesi foto produk dilaksanakan dengan mengambil foto dari beberapa produk terbaru yang nantinya akan diunggah di akun Instagram dan dijadikan katalog online agar para konsumen dapat leluasa melihat-lihat koleksi produk. Pada bio Instagram Banyu Biru Craft juga ditautkan tautan Shopee Banyu Biru Craft yang berfungsi saat konsumen sudah melihat-lihat produk dari laman Instagram dan tertarik untuk membeli maka langsung dapat melakukan pemesanan via akun Shopee. 


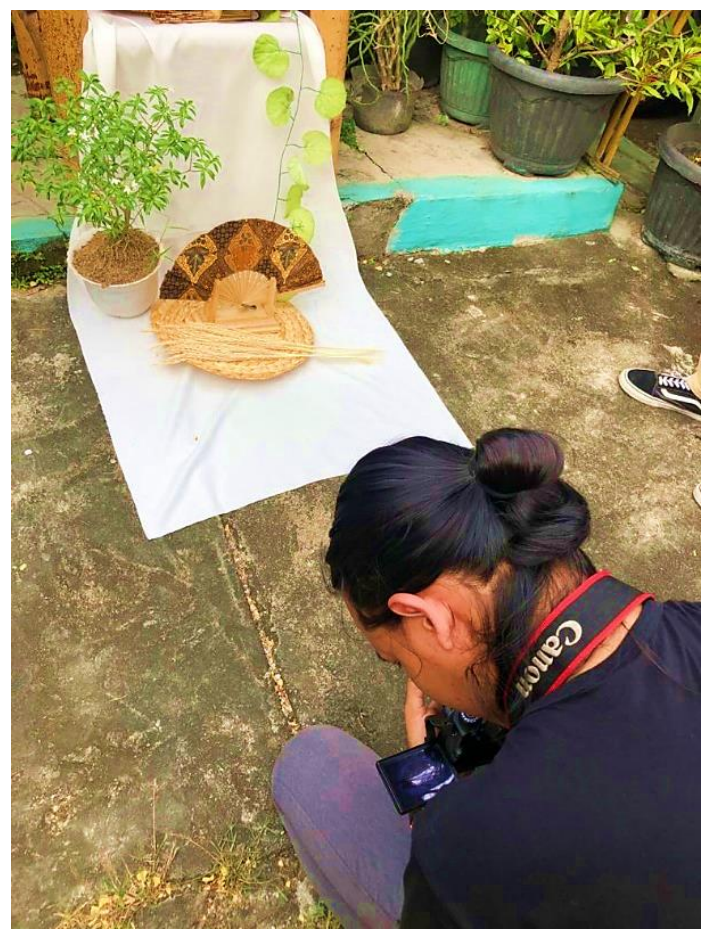

Gambar 1. Pengambilan foto produk mitra

c. Pelatihan digital marketing (pemasaran produk secara online)

Mengikutsertakan UMKM mitra dalam kegiatan yang diselenggarakan oleh LP3M Universitas Muhammadiyah Yogyakarta dengan menggunakan metode pelatihan dan diskusi secara online kepada pihak UMKM terkait bagaimana cara pemasaran menggunakan marketplace seperti, Shopee, Lazada, Tokopedia, dan Bukalapak (Gambar 2 dan 3). Diharapkan dengan mengikuti seminar ini para UMKM yang bermitra dengan kelompok-kelompok KKN IT UMY akan mendapatkan new insight untuk memulai aktif melakukan pemasaran secara online melalui berbagai macam marketplace yang tersedia seperti Shopee, Lazada, Tokopedia, OLX dan lain sebagainya.

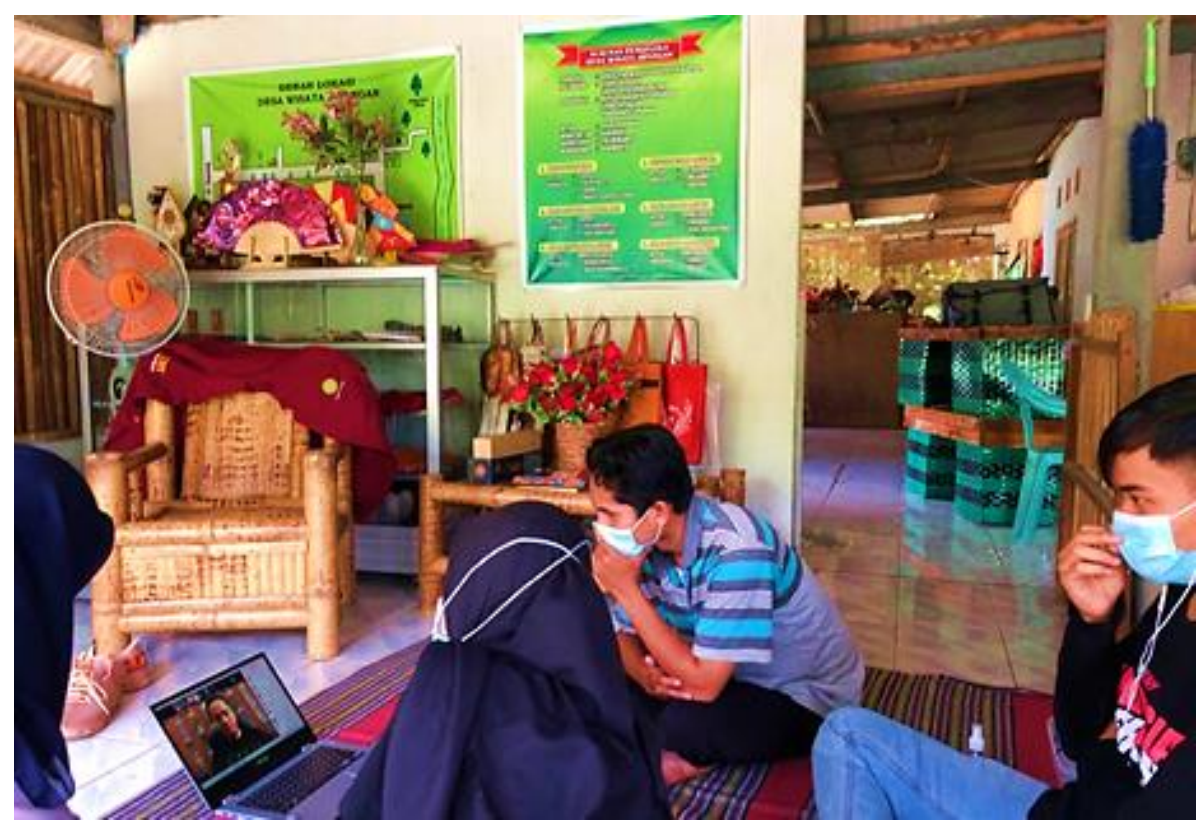

Gambar 2. Pendampingan seminar dan pameran UMKM virtual 


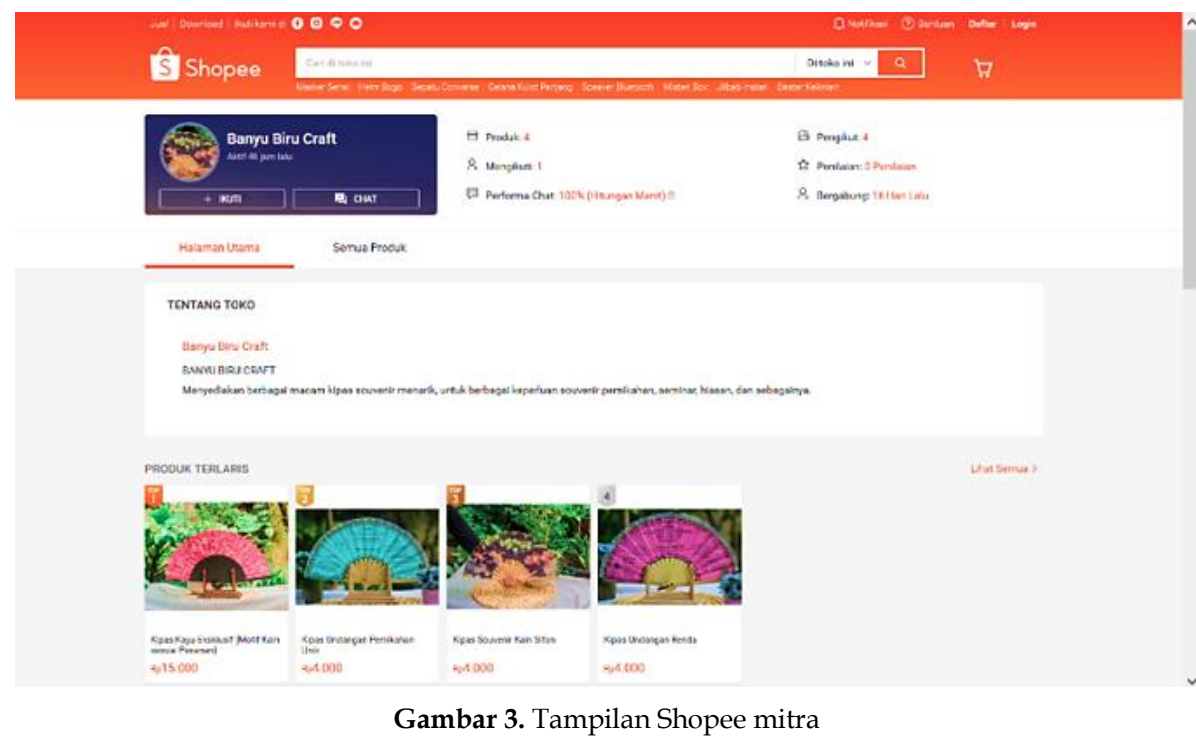

2. Pencatatan administrasi UMKM

Tuntutan terhadap UMKM untuk meningkatkan kinerja, profesionalisme, dan akuntabilitas dalam menjalankan aktivitasnya semakin tinggi, maka diperlukan pengelolaan administrasi keuangan yang baik dan memadai demi kemajuan dan untuk menghadapi tantangan di masa yang akan datang. Namun, dalam penerapannya di lapangan dapat ditentukan bahwa pada umumnya UMKM tidak melakukan pengelolaan administrasi keuangan dengan baik dan benar, sehingga menyajikan laporan keuangan jauh dari standar akuntansi (Sampoerna, 2018). Oleh karena itu, tim pengabdian melakukan pendampingan pembenahan pembukuan keuangan usaha dengan metode pencatatan soft file. Kegiatan pendampingan ini dilakukan dengan memberikan tutorial tata cara pengoperasian aplikasi Buku Kas secara langsung kepada Mitra (Gambar 4).

3. Penyuluhan terkait protokol kesehatan

Dalam rangka menerapkan protokol kesehatan selama kegiatan pengabdian berlangsung maka kelompok pengabdian ini menghibahkan beberapa alat penunjang baik kepada mitra ataupun kepada masyarakat sekitar. Kepada para mitra, kami menghibahkan tempat cuci tangan serta sabun cuci tangan. Kepada masyarakat, juga dihibahkan masker dan wastafel portable, serta tempat cuci tangan yang diletakkan di mushola dekat dengan lokasi mitra (Gambar5).

4. Pendampingan pembuatan frozen food secara daring

Guna meningkatkan produktivitas ibu-ibu yang tergabung dalam kelompok sosial masyarakat Dasawisma Cempaka 1, tim pengabdian memberikan tiga video tutorial pembuatan frozen food yang juga berpotensi untuk dikembangkan menjadi usaha yang dapat menggerakkan perekonomian. Pelatihan pembuatan frozen food dilakukan secara daring demi mencegah terjadinya penyebaran virus Corona (Gambar 6).

Pengembangan kemampuan mitra dalam meningkatkan produk mereka, termasuk promosi, menjadi bagian upaya dari pelestarian kearifan lokal Desa Bangunjiwo, mengingat bahan-bahan yang mitra gunakan berasalan daerah mereka sendiri. Kearifan lokal menjadi sesuai yang sejauh ini menjadi ciri khas penting dalam masyarakat yang bisa dikembangkan dan menjadi pondasi yang bagus (Rozaki et al., 2020). 


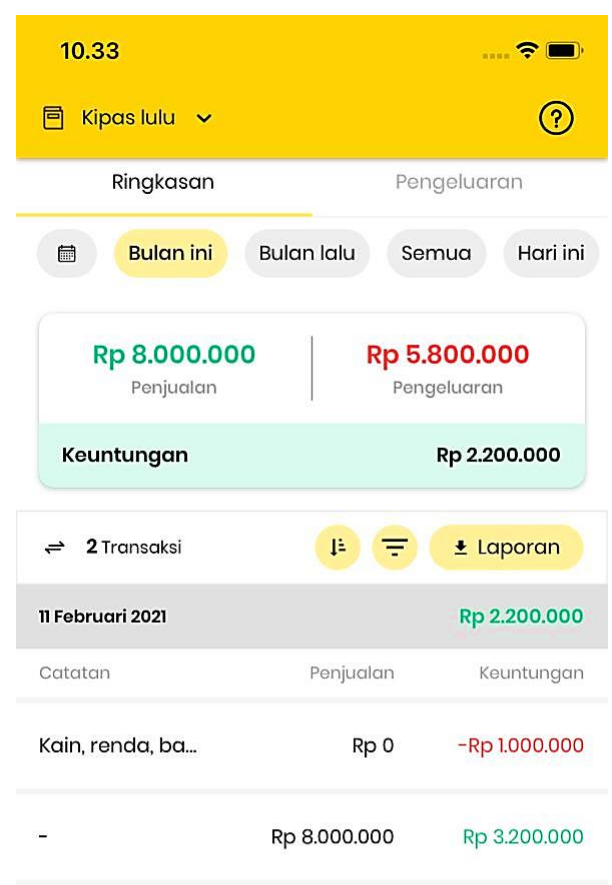

\section{+ TAMBAH TRANSAKSI}

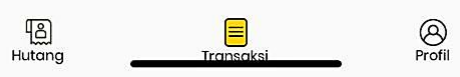

Gambar 4. Tampilan pembukuan keuangan mitra lewat aplikasi

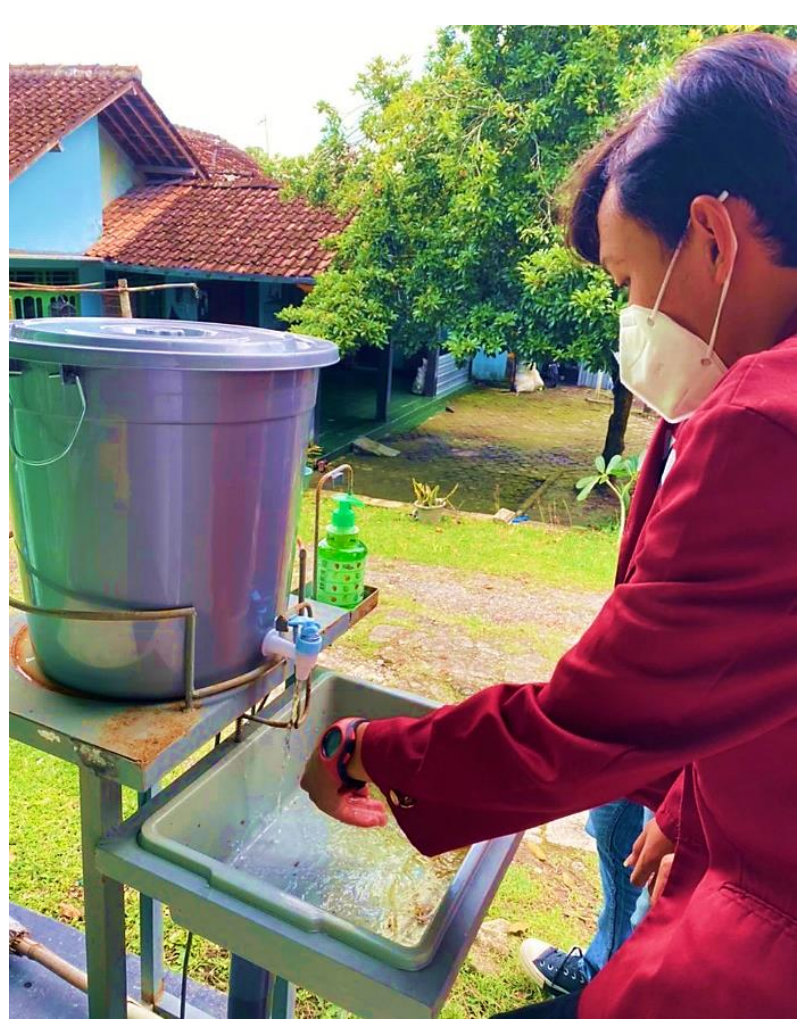

Gambar 5. Hibah tempat cuci tangan 


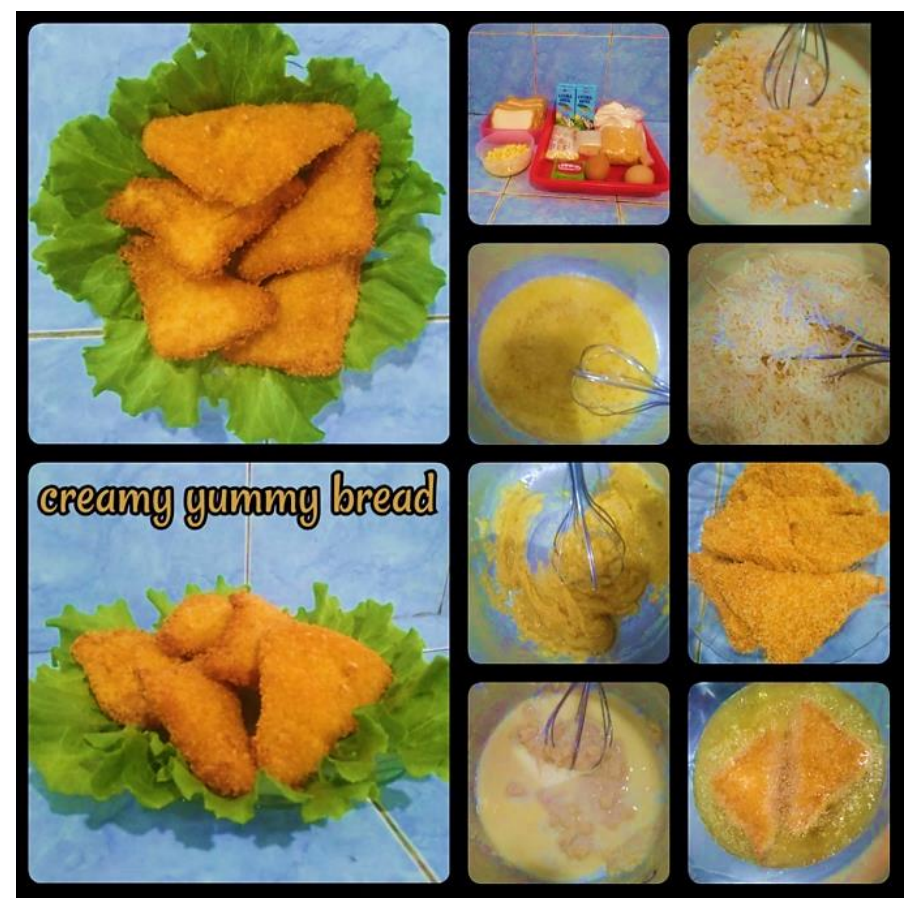

Gambar 6. Produk frozen food hasil pendampingan

\section{KESIMPULAN}

Kegiatan pengabdian ini berjalan dengan baik berkat kerjasama semua mitra. Upaya peningkatan kapasitas pemasaran mitra dirasa meningkat dengan adanya pengabdian ini, mitra menjadi sadar bahwa pada masa digital seperti ini, usaha mereka harus lebih up to date terhadap zaman dan juga adaptif terhadap permasalah yang sudah ada. Mitra Kelompok Dasa Wisma juga mengalami kenaikan kapasitas terutama dalam ketrampilan mereka dalam mengolah makanan menjadi frozen food. Harapannya mitra bisa terus berkembang dan mampu beradaptasi ketika masalah seperti pandemi ini muncul.

\section{UCAPAN TERIMA KASIH}

Penulis menyampaikan ucapan terimakasih kepada Lembaga Penelitian, Pengabdian dan Publikasi (LP3M) Universitas Muhammadiyah Yogyakarta atas bantuan dana dalam Skema KKN PPM untuk pelaksanaan pengabdian ini.

\section{REFERENSI}

Badan Pusat Statistik Kabupaten Bantul. 2020. Kecamatan Kasihan dalam Angka 2019. https://bantulkab.bps.go.id/publication/2019/09/26/b45127d570dd8908762ca50a/kecamatan-kasihandalam-angka-2019.html

Djalante, R., Lassa, J., Setiamarga, D., Sudjatma, A., Indrawan, M., Haryanto, B., et al. 2020. Review and Analysis of Current Responses to COVID-19 in Indonesia: Period of January to March 2020. Progress in Disaster Science. 6:100091. https://dx.doi.org/10.1016/j.pdisas.2020.100091

Fidiana, Rochdianingrum, W.A., Retnani, E.D., Widyawati, D. 2020. Peningkatan Kapabilitas dan Performa UMKM melalui Monitoring dan Pendampingan. PengabdianMu: Jurnal Ilmiah Pengabdian Kepada Masyarakat. 5(4):376-382. https://doi.org/10.33084/pengabdianmu.v5i4.1268

Hashim, N.A. 2017. Embracing the Instagram Waves -The New Business Episode to the Potential Entrepreneurs. Journal of Entrepreneurship and Business Innovation. 4(2):13-29. https://doi.org/10.5296/jebi.v4i2.12092 
Irawan, D. 2020. Peningkatan Daya Saing Usaha Micro Kecil dan Menengah Melalui Jaringan Usaha. Coopetition : Jurnal Ilmiah Manajemen. 11(2):103-116. https:/ /doi.org/10.32670/coopetition.v11i2.82

Kar, S.K., Arafat, S.M.Y., Sharma, P., Dixit, A., Marthoenis, M., Kabir, R. 2020. COVID-19 pandemic and addiction: Current problems and future concerns. Asian Journal of Psychiatry. 51:102064. https://doi.org/10.1016/j.ajp.2020.102064

Kholisotin, L., Sadar, S. 2021. Bimbingan Spiritual Untuk Meningkatkan Coping Stress Dalam Pandemi Covid-19 Pada Pengajian 'Aisyiyah Ranting Kereng Bengkirai. PengabdianMu: Jurnal Imiah Pengabdian Kepada Masyarakat. 6(2):113-118. https://doi.org/10.33084/pengabdianmu.v6i2.1861

Latiff, Z.A., Safiee, N.A.S. 2015. New Business Set Up for Branding Strategies on Social Media - Instagram. Procedia Computer Science. 72:13-23. https://doi.org/10.1016/j.procs.2015.12.100

Lubis, T.A., Junaidi. 2016. Pemanfaatan Teknologi Informasi Pada Usaha Mikro Kecil dan Menengah di Kota Jambi. Jurnal Perspektif Pembiayaan Dan Pembangunan Daerah.3(3):163-174. https://doi.org/10.22437/ppd.v3i3.3535

Mboera, L.E.G., Akipede, G.O., Banerjee, A., Cuevas, L.E., Czypionka, T., Khan, M., et al. 2020. Mitigating lockdown challenges in response to COVID-19 in Sub-Saharan Africa. International Journal of Infectious Diseases. 96:308-310. https://doi.org/10.1016/j.ijid.2020.05.018

Nicola, M., Alsafi, Z., Sohrabi, C., Kerwan, A., Al-Jabir, A., Iosifidis, C., et al. 2020. The socio-economic implications of the coronavirus pandemic (COVID-19): A review. International Journal of Surgery. 78:185-193. https://doi.org/10.1016/j.ijsu.2020.04.018

Rozaki, Z. 2020. COVID-19, Agriculture, and Food Security in Indonesia. Reviews in Agricultural Science. 8:243-260. https://doi.org/10.7831/ras.8.0_243

Rozaki, Z., Wijaya, O., Keothoumma, K., Salim, E. 2020. A Review: Farmers' Local Wisdom on Natural Resources. Andalasian International Journal of Agricultural and Natural Sciences. 1(1):25-32. https://doi.org/10.25077/aijans.v1.i01.2532.2020

Sampoerna, D. 2018. Pembinaan Tatakelola Administrasi Keuangan Usaha Anggota Koperasi Maju Bersama di Kelurahan Jurang Mangu Timur, Pondok Aren - Tangerang Selatan. Jurnal Pelayanan dan Pengabdian Masyarakat (Pamas). 2(2):14-25. https://doi.org/10.52643/pamas.v2i2.398

Setyowardhani, H., Susanti, H., Riyanto. 2019. Optimalisasi Media Sosial Sebagai Alat Promosi Untuk Desa Wisata Lebakmuncang. Dinamisia: Jurnal Pengabdian Kepada Masyarakat. 3(Special Issue 1):19-26. https://doi.org/10.31849/dinamisia.v3i2.2848

Simms, C., Rowson, M. 2003. Reassessment of health effects of the Indonesian economic crisis: donors versus the data. Lancet. 361(9366):1382-1385. https://doi.org/10.1016/s0140-6736(03)13076-0

Taufik, Ayuningtyas, E.A. 2020. Dampak Pandemi Covid 19 terhadap Bisnis dan Eksistensi Platform Online. Jurnal Pengembangan Wiraswasta. 22(1):21-32. http://dx.doi.org/10.33370/jpw.v22i01.389 